Article

\title{
Essential Oil from Cryptomeria japonica Induces Apoptosis in Human Oral Epidermoid Carcinoma Cells via Mitochondrial Stress and Activation of Caspases
}

\section{Jeong-Dan Cha ${ }^{1}$ and Ji-Young Kim ${ }^{2, *}$}

1 Department of Dental Hygiene, College of Natural Sciences, Dongeui University, Busan 614-714, Korea

2 Department of Dental Hygiene, Ulsan College, San 160-1, Hwajeong-Dong, Dong-Gu, Ulsan 682-715, Korea

* Author to whom correspondence should be addressed; E-Mail: jykim@mail.uc.ac.kr; Tel.: +82-52-230-0797; H.P.: +82-10-9280-2441; Fax: +82-52-230-0795.

Received: 5 March 2012; in revised form: 5 March 2012 / Accepted: 20 March 2012 / Published: 30 March 2012

\begin{abstract}
Cryptomeria japonica D. Don (C. japonica) has been used in traditional medicines from Asia for a variety of indications, including liver ailments, and an antitussive, and for its antiulcer activities. We examined the cell viability and apoptosis of KB cells treated with $C$. japonica essential oil at several concentrations for $12 \mathrm{~h}$ by MTT assay, Hoechst-33258 dye staining, DNA fragmentation, flow cytometry (cell cycle), and Western blotting for mitochondria stress, activation of caspases, and poly (ADP-ribose) polymerase. The essential oil induced the apoptosis of KB cells in a dose-dependent manner, which was verified by DNA fragmentation, appearance of apoptotic bodies, and the sub-G1 ratio. The essential oil also induced rapid and transient caspase- 3 activity and cleavage of PARP of the KB cells. Treating the cells with the oil also caused changes in the mitochondrial level of the Bcl-2 family proteins such as Bcl-2 and Bax, thereby inducing the release of cytochrome $c$ into the cytosol. The essential oil of $C$. japonica may have potential as a cancer chemopreventive and therapeutic agent.
\end{abstract}

Keywords: Cryptomeria japonica; essential oil; apoptosis; mitochondrial stress; caspases 


\section{Introduction}

Apoptosis is an important phenomenon in cytotoxicity induced by anticancer drugs. The execution of apoptosis, or programmed cell death, is associated with characteristic morphological and biochemical changes mediated by a series of gene regulation and cell-signaling pathways [1-3]. The mitochondrial apoptotic pathway plays a pivotal role in the apoptotic cell death $[1,4]$. The release of cytochrome $c$ from mitochrondria in response to proapoptotic signals has been suggested as an initiating event in the apoptotic process [4,5]. Cytochrome $c$ released from mitochondria is associated with apoptosis protease activating factor (Apaf-1) and pro-caspase-9, triggering the activation of caspase-3 and resulting in cell death [5-8]. The inhibition of apoptosis, a universal and efficient cellular suicide pathway, is a hallmark characteristic of cancer $[9,10]$.

Sugi, Cryptomeria japonica D. Don (Taxodiaceae), is an important forest tree because of its excellent characteristics, including rapid growth, straight bole, ready regeneration, and soft wood with a pleasant color and scent. In addition, various constituents of $C$. japonica have been employed as herbal medicines. The leaves include bioactive compounds, since cedar leaves contain essential oils and flavones, among other compounds [11-13]. The essential oil from the leaves of $C$. japonica inhibits the formation of gastric mucosal lesions in rats, and several terpenes from this essential oil have shown antiulcer activities [13,14]. In a previous study, we isolated the essential oil from C. japonica, and identified its chemical composition using gas chromatography (GC)/mass spectrometry (MS) analyses. The results showed that the essential oil of $C$. japonica contains 68 compounds, representing $95.82 \%$ of the total oil content, with $\alpha$-pinene $(6.07 \%)$, sabinene $(8.86 \%)$, terpinen-4-ol (9.77\%), $\alpha$-terpineol (6.13\%), elemol (11.17\%) and 10(15)-cadinen-4-ol (7.16\%), comprising the main portion of the oil. In addition, the essential oil exhibits potent antimicrobial activity against many types of facultative and obligate anaerobic bacteria [15]. Furthermore, the oil was demonstrated to possess excellent antitermite and larvicidal effects against mosquito larvae $[16,17]$.

This study investigated the possible mechanism(s) of the apoptosis mediated by the essential oil of C. japonica. The results demonstrate for the first time that the essential oil induces apoptosis in the KB cells through a mitochondria- and caspase-dependent mechanism.

\section{Results}

\subsection{Effect of Essential oil on KB Cell Proliferation}

KB cells were treated several times with the essential oil at various concentrations, and cell viability was determined using the MTT assay. As shown in Figure 1, essential oil inhibited the growth of KB cells in a dose- and time-dependent manner. Cell viability was obviously inhibited by a 12 -h treatment of $0.2 \mathrm{mg} / \mathrm{mL}$ essential oil $(p<0.05)$.

\subsection{Effect of Essential Oil on Cell Cycle Phase Distribution in KB Cells}

The redistribution of cell cycle phases was analyzed after treatment with various concentrations of the essential oil for $12 \mathrm{~h}$. The proportion of cells in the G2/M-phase was decreased in essential 
oil-treated cells when compared with control. The number of cells in G0/G1 and S-phase was increased in essential oil-treated cells at concentrations of 0.2 and $0.4 \mathrm{mg} / \mathrm{mL}$ when compared with control. Cells with sub-G1 DNA content, a hallmark of apoptosis, were seen in the essential oil-treated group following $12 \mathrm{~h}$ exposure at concentrations of 0.2 and $0.4 \mathrm{mg} / \mathrm{mL}$ (Figure 2).

Figure 1. Effect of essential oil from Cryptomeria japonica on cell proliferation in $\mathrm{KB}$ cells. KB cells were plated into 24 well plates and treated several times with different concentrations (A) of the essential oil (B). Cell proliferation was determined by the MTT assay and is expressed as percentage of the absorbance value obtained without essential oil. The results are expressed as the mean \pm S.E. from three different experiments with triplicate cultures. ${ }^{*} p<0.05$ compared with control.
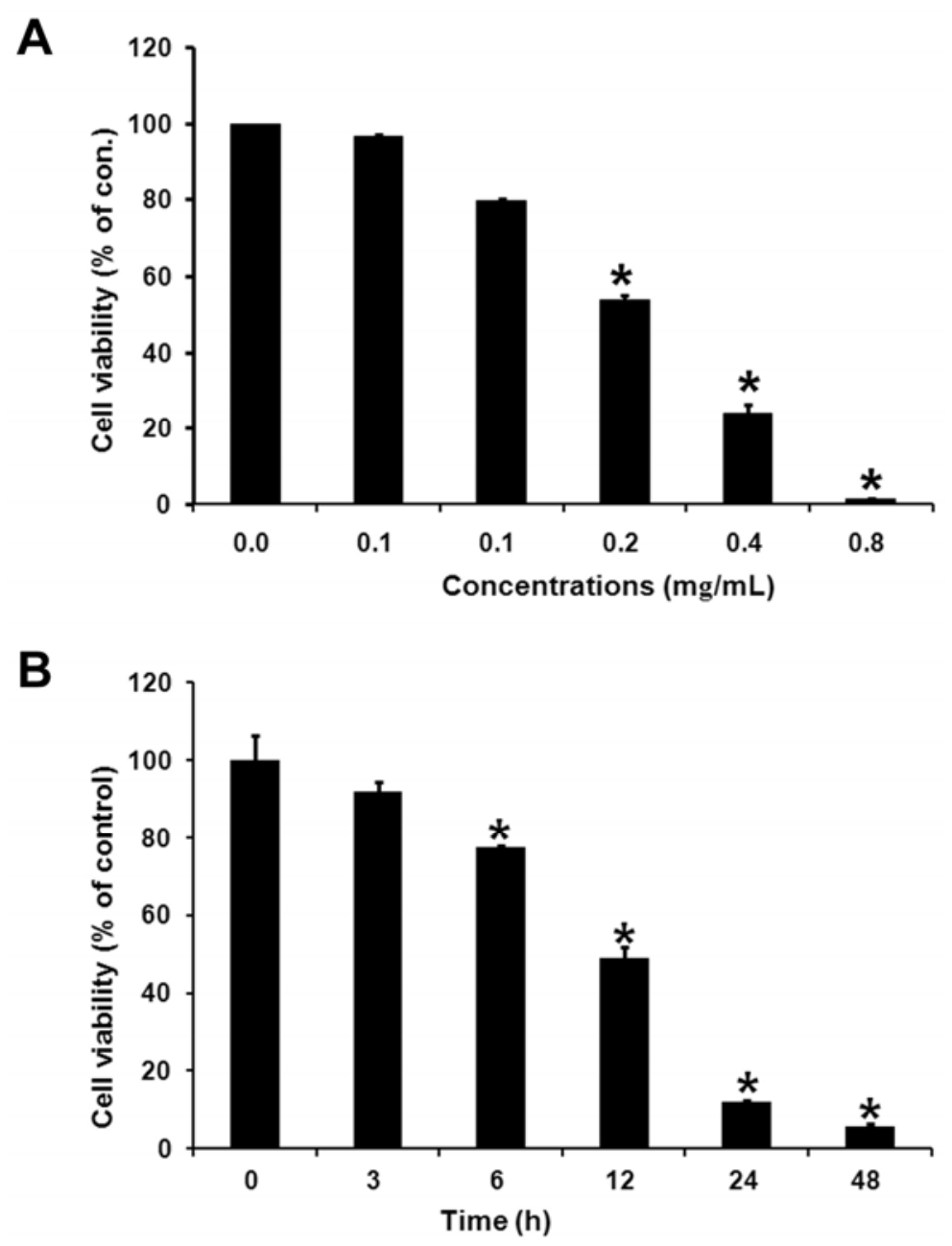

\subsection{Effect of Essential Oil on Determination of Morphological Changes in KB Cells}

Nucleic acid staining with Hoechst 33258 revealed typical apoptotic nuclei, which exhibited highly fluorescent condensed chromatin in cells treated with the essential oil (Figure 3). The morphological changes and cell death of $\mathrm{KB}$ cells were significantly increased in a dose-dependent manner at essential oil concentrations of 0.2 and $0.4 \mathrm{mg} / \mathrm{mL}$. Most cells were detached from the dishes, and cell rounding and shrinking occurred at the same concentrations of the essential oil (Figure 3 ). 
Molecules 2012, 17

3893

Figure 2. Effect of the essential oil of Cryptomeria japonica on cell cycle phase distribution in $\mathrm{KB}$ cells. $\mathrm{KB}$ cells were treated for $12 \mathrm{~h}$ with 0.2 and $0.4 \mathrm{mg} / \mathrm{mL}$ of the essential oil. Following the treatment, cells were collected for three different experiments examining apoptosis induction. The percentages of apoptotic cells were determined by propidium iodide staining followed by flow cytometric analysis. Data are representative of at least three independent experiments.
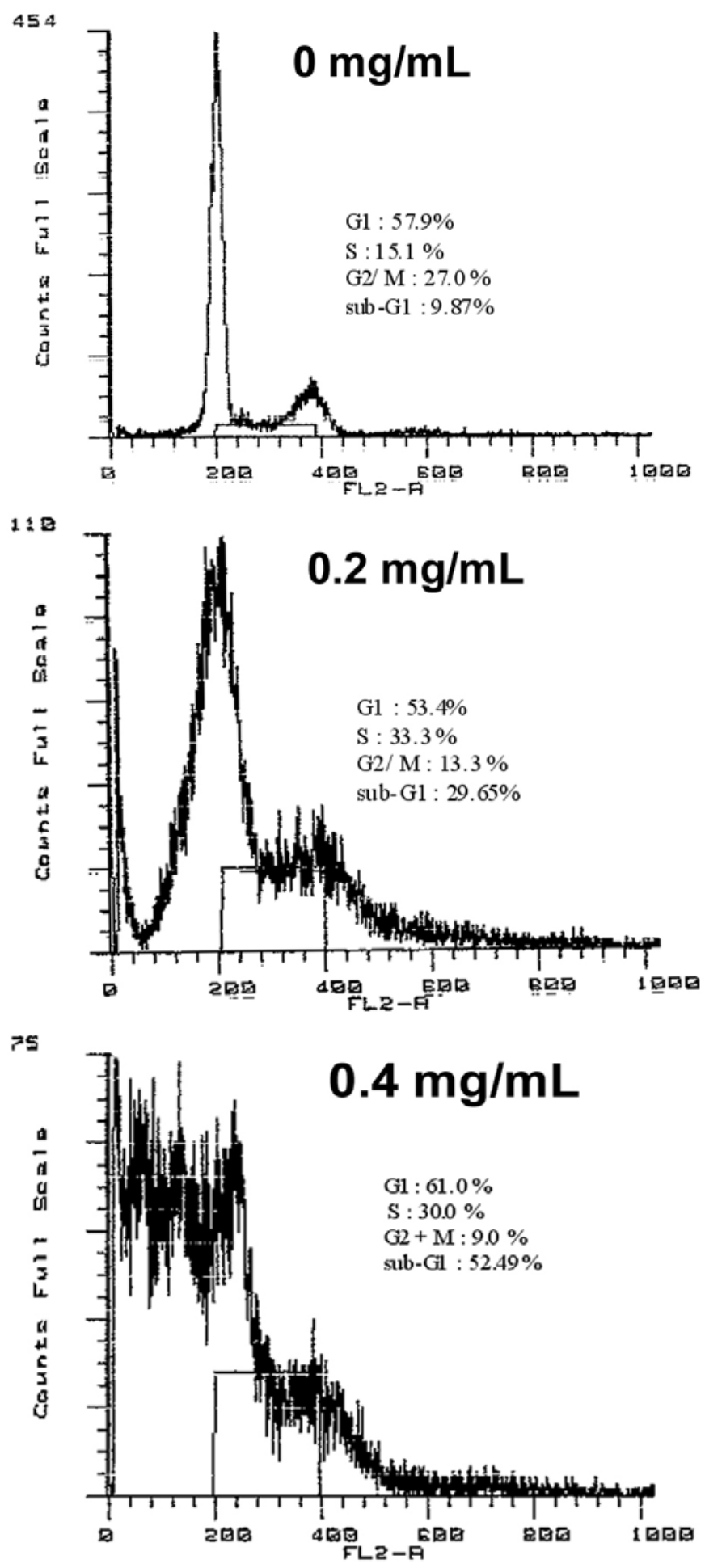
Figure 3. Effect of the essential oil of Cryptomeria japonica on determination of morphological changes in $\mathrm{KB}$ cells. $\mathrm{KB}$ cells were treated with 0.2 and $0.4 \mathrm{mg} / \mathrm{mL}$ of the essential oil for $12 \mathrm{~h}$. Following the treatment, cells were collected for three kinds of experiments for apoptosis induction. The morphologic change was assessed by fluorescence microscopy after staining with Hoechst 33258. The apoptotic cells are indicated with arrows. Normal nuclear morphology is observed in untreated cells. In contrast, small, fragmented, and condensed nuclei with typical apoptotic morphology were observed in treated cells.

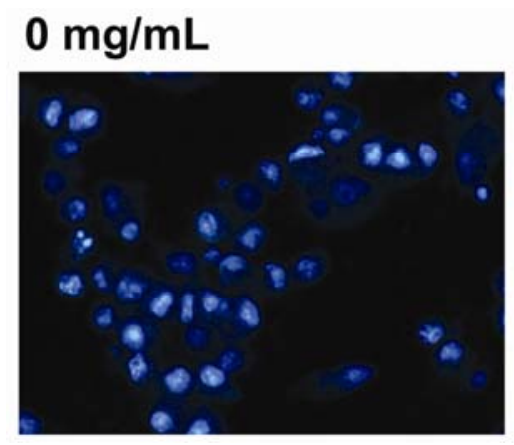

\section{$0.2 \mathrm{mg} / \mathrm{mL}$}

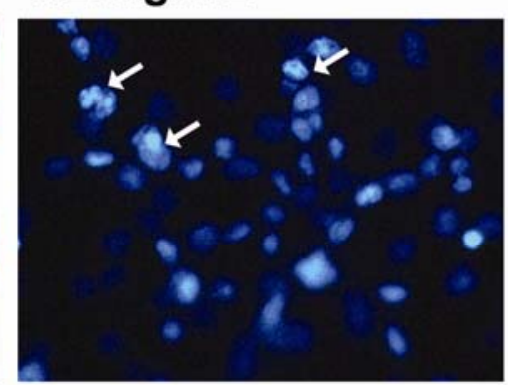

\section{$0.4 \mathrm{mg} / \mathrm{mL}$}

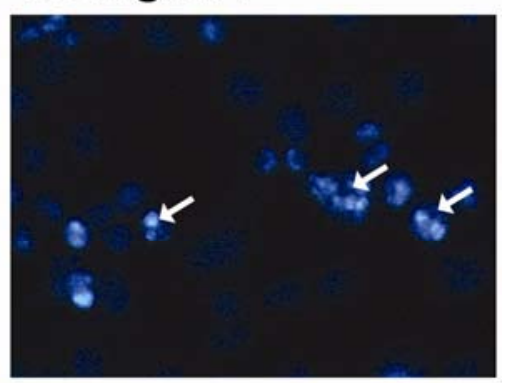

\subsection{Effect of Essential Oil on DNA Fragmentation in KB Cells}

To determine whether the essential oil could induce apoptosis in KB cells, we assessed DNA fragmentation, which is a biochemical hallmark for apoptosis. Essential oil induced endonucleolytic DNA cleavage in a dose-dependent manner (Figure 4). The efficient induction of apoptosis was observed at essential oil concentrations of 0.2 and $0.4 \mathrm{mg} / \mathrm{mL}$ in KB cells treated for $12 \mathrm{~h}$.

Figure 4. Effect of the essential oil of Cryptomeria japonica on DNA fragmentation in KB cells. $\mathrm{KB}$ cells were treated with 0.2 and $0.4 \mathrm{mg} / \mathrm{mL}$ of the essential oil for $12 \mathrm{~h}$. Following the treatment, cells were collected for three kinds of experiments assessing apoptosis induction. For DNA fragmentation analysis, intracellular DNA was isolated and analyzed by $2.0 \%$ agarose gel electrophoresis.

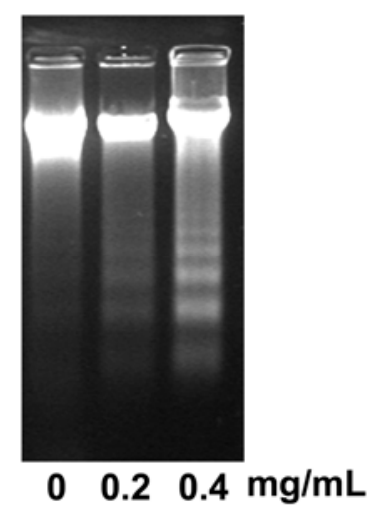

\subsection{Essential Oil-Mediated Apoptosis of KB Cells Involves a Caspase-Dependent Mechanism}

Caspase activities were measured by Western blot analyses because the activation of caspases such as caspase-3, -8 , and -9 is one of the most common processes occurring in apoptotic signaling 
events [19]. As shown in Figure 5A, a dose-dependent activation of caspase-8 was observed after treating $\mathrm{KB}$ cells with the essential oil. In particular, approximately $50 \%$ and $70 \%$ degradation of procaspase- 8 and -9 were observed when the cells were exposed to 0.2 and $0.4 \mathrm{mg} / \mathrm{mL}$ of the essential oil for $12 \mathrm{~h}$, respectively. In contrast, the oil-mediated degradation of procaspase- 3 was more apparent than that of procaspase- 8 and -9 . KB cells were then treated with $0.2 \mathrm{mg} / \mathrm{mL}$ of the essential oil for $12 \mathrm{~h}$ in the presence or absence of $50 \mu \mathrm{M}$ of z-VAD-fmk, z-IETD-fmk or z-LEHD-fmk to further confirm that caspase activation plays a critical role in the oil-mediated apoptotic process. These inhibitors significantly inhibited the oil-induced cytotoxicity in the cells (Figure 5B). In particular, the inhibitory effect of z-VAD-fmk or z-LEHD-fmk was higher than z-IETD-fmk. This suggests that the caspase-dependent pathway is closely related to the oil-induced cell death of KB cells. To further confirm the apoptosis induced by the essential oil, we investigated the cleavage of poly (ADP-ribose polymerase poly (PARP) in KB-treated cells. Treatment of KB cells with 0.2 and $0.4 \mathrm{mg} / \mathrm{mL}$ essential oil caused a proteolytic cleavage of PARP, with accumulation of the characteristic $85-\mathrm{kDa}$ fragments and a concomitant disappearance of the full-length 116-kDa protein (Figure 5).

Figure 5. Essential oil-mediated apoptosis of $\mathrm{KB}$ cells involves a caspase-dependent mechanism. (A) KB cells were exposed to the indicated concentrations of the essential oil for $12 \mathrm{~h}$, and the expression of several procaspases was determined by Western blot analysis; (B) The cells were also pretreated with $50 \mu \mathrm{M}$ of caspase inhibitors z-VAD-fmk, z-IETD-fmk, or z-LEHD-fmk for $1 \mathrm{~h}$ before exposing them to $0.2 \mathrm{mg} / \mathrm{mL}$ of the essential oil and incubating for an additional12 h. MTT-reducing activity was then determined.

A

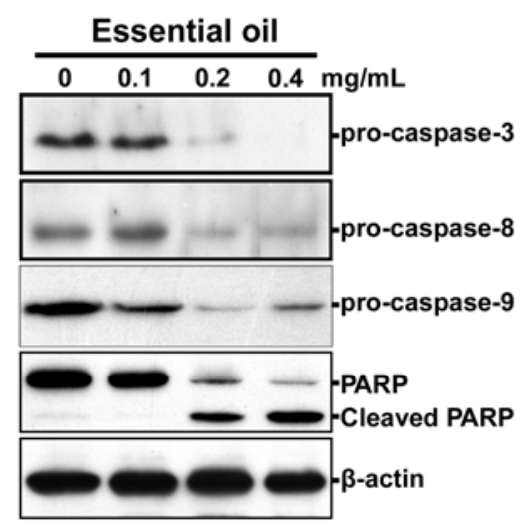

B

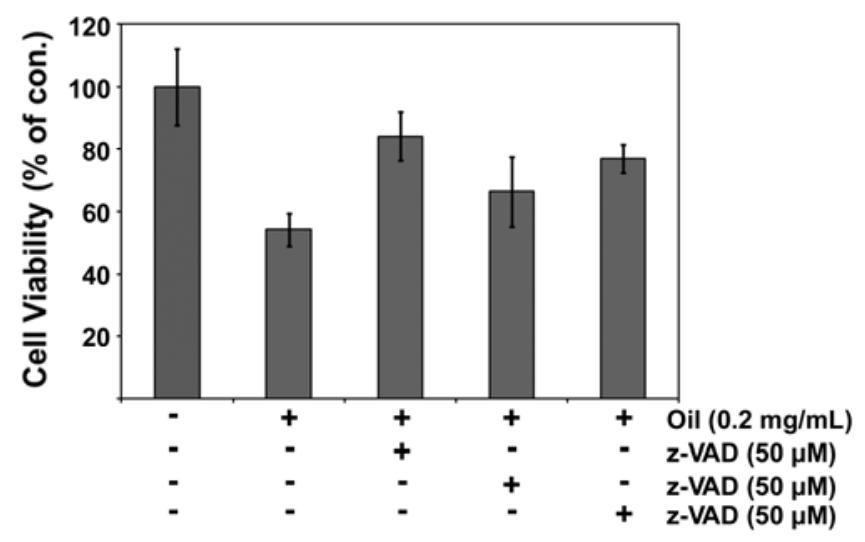




\subsection{Mitochondrial Stress is an Important Event in the Essential Oil-Mediated Apoptosis of KB Cells}

Changes in the induction of Bcl-2 family proteins are closely related to an imbalance in the mitochondrial homeostasis, which leads to apoptosis [5,7]. In particular, the release of cytochrome $c$ into the cytosol plays an important role in the execution of apoptosis in a number of different cell types, which is tightly regulated by the equilibrium between the antiapoptotic Bcl-2 and pro-apoptotic Bad and Bax $[7,18,20]$. Essential oil treatment increased the intensity of the bands corresponding to Bax protein in mitochondrial fractions, but significantly reduced the level of Bcl-2 protein (Figure 6). In addition, the amount of cytosolic cytochrome $c$ was apparently higher in the cells treated for $12 \mathrm{~h}$ with $0.2 \mathrm{mg} / \mathrm{mL}$ of the essential oil. Therefore, mitochondrial stress might play a role in the essential oil-mediated apoptosis of KB cells.

Figure 6. Involvement of mitochondrial stress in the essential oil-mediated apoptosis of KB cells. The cells were treated with the indicated doses of the essential oil for $12 \mathrm{~h}$. Cell lysates were analyzed by $12 \%$ sodium dodecyl sulfate-polyacrylamide gel electrophoresis followed by immunoblot analysis. A representative result from three independent experiments is shown. $\mathrm{M}$ and $\mathrm{C}$ represent the mitochondria and cytosolic fractions, respectively.

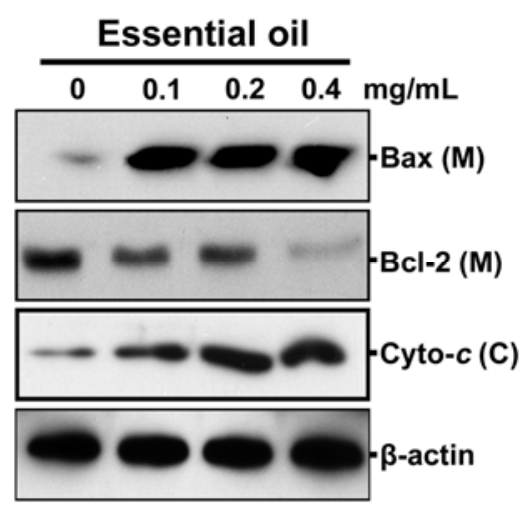

\section{Discussion}

Several studies focused on developing effective anticancer and chemopreventive approaches have examined the use of essential oils as natural bioactive substances that can induce sensitive growth inhibition and apoptosis in cancer cells [9,21-24]. The essential oil of $C$. japonica is a highly purified volatile extract that contains a large number of aromatic components [15-17]. Previously, we reported that the essential oil of $C$. japonica is comprised of 68 compounds with the main compounds $\alpha$-pinene $(6.07 \%)$, sabinene (8.86\%), terpinen-4-ol (9.77\%), $\alpha$-terpineol $(6.13 \%)$, elemol (11.17\%), and 10(15)-cadinen-4-ol (7.16\%) demonstrating excellent antimicrobial activity against many types of facultative and obligate anaerobic bacteria [15]. In the present study, we investigated the effect of the essential oil of $C$. japonica on the cell proliferation and induction of apoptosis of $\mathrm{KB}$ cells. Apoptosis is a type of physiological cell death that is accompanied by a specialized series of cellular events such as chromatin condensation, DNA fragmentation, cytoplasmic membrane blebbing, and cell shrinkage $[10,21,25]$. KB cell viability was inhibited by the essential oil in a dose-dependent manner. Also, KB cells treated with the essential oil displayed morphologic changes such as apoptotic bodies and chromatin condensation, as well as DNA fragmentation into oligonucleosomal-sized fragments. In 
addition, cytometric analysis showed that the cells treated with the essential oil accumulated in the G2/M-phase and S-phase in $12 \mathrm{~h}$, compared to control. Sub-G1 peaks, which represent the cell population containing apoptotic nuclear fragments, were markedly increased after treatment with essential oil in a dose-dependent manner for $12 \mathrm{~h}$.

Apoptosis is a tightly regulated progress that is under the control of several signaling pathways, such as caspase and mitochondrial pathways [2,4,6,]. Cytochrome $c$ release from mitochondrion to cytosol causes caspase-9-dependent activation of caspase-3 and cleavage of the DNA reparatory protein PARP [20,25,26]. At concentrations more than $0.1 \mathrm{mg} / \mathrm{mL}$, the essential oil induced processing of pro-caspase-3, -8 and -9 and into active forms within $12 \mathrm{~h}$. After caspase- 3 activation, some specific substrates for caspase-3 such as PARP are cleaved, which are important for occurrence of apoptosis [26,27]. The present results showed that caspase- 3 was activated by cleavage of procaspase during apoptosis of $\mathrm{KB}$ cells induced by the essential oil. This suggests that the essential oil-mediated apoptosis of KB cells is caspase-dependent, which was confirmed by the results showing that pretreating the cells with the caspase inhibitors significantly protected the cells from the oil induced cytotoxicity. Furthermore, essential oil also caused specific activation by cleavage of the caspase-3 substrate, PARP, providing further evidence of apoptosis. PARP, a nuclear protein implicated in DNA repair, is one of the earliest proteins targeted for a specific cleavage to the signature $85-\mathrm{kDa}$ fragment during apoptosis [27]. In the apoptotic responses to various cellular stresses, mitochondria play an important role by releasing mitochondrial cytochrome $c$ into the cytoplasm $[18,20]$. Bcl-2 is an integral membrane protein that prevents apoptosis by inhibiting the efflux of the proteins, whereas Bax and Bid are translocated from the cytoplasm to the outer mitochondrial membrane, where they trigger apoptosis via the release of mitochondrial apoptotic factors [28,29]. Therefore, mitochondrial stress mediated by the Bcl-2 family protein is a major event in the execution of apoptotic processes, which is also believed to be closely related to the essential oil-mediated apoptosis in KB cells. This suggests that caspase-independent pathways are also important in the mitochondria-mediated apoptotic mechanism.

\section{Experimental}

\subsection{Plant Material and Isolation of the Essential Oil}

The aerial parts of C. japonica were collected in September, 1999 from the area of Mt. Wansanchilbong in Korea. The plant's identity was confirmed by Bong-Seop Kil, College of Natural Science, Wonkwang University. A voucher specimen (DJ-99-C20) was deposited at the herbarium of the College of Natural Science, Wonkwang University. The aerial parts of $C$. japonica $(1 \mathrm{~kg})$ were air dried and then distilled for $3 \mathrm{~h}$, using a modified Clevenger type apparatus in order to obtain the essential oil. Anhydrous sodium sulphate was used to absorb the little water that the essential oil contained. The essential oil was stored on deep freezer $\left(-70{ }^{\circ} \mathrm{C}\right)$ to minimize the loss of volatile compounds. The essential oil isolated from C. japonica [15], was freshly dissolved in the culture dedia.

\subsection{Cell Culture}

KB cells, human oral epidermoid carcinoma cell line (ATCC CCL-17; American Type Culture Collection, Rockville, MD, USA) were grown in Dulbecco's Modified Eagle medium (DMEM; Gibco, 
Grand Island, NY, USA) supplemented with 10\% heat-inactivated fetal bovine serum (Gibco), $100 \mathrm{U} / \mathrm{mL}$ penicillin, and $10 \mu \mathrm{g} / \mathrm{mL}$ streptomycin. $\mathrm{KB}$ cells were maintained as monolayer in plastic culture plate at $37^{\circ} \mathrm{C}$ in a humidified atmosphere containing $5 \% \mathrm{CO}_{2}$.

\subsection{Measurement of Cell Viability}

MTT was used to examine the cell viability. Briefly, the cultured KB cells were exposed to the essential oil. At various exposure times, a MTT solution $(10 \mu \mathrm{L}, 5 \mathrm{mg} / \mathrm{mL}$ in PBS as stock solution) was added to each well, and the cells were incubated for a further $4 \mathrm{~h}$ at $37{ }^{\circ} \mathrm{C}$. Seventy microliters of acidic isopropanol was then added to each well, and the absorbance of the plates was read at $560 \mathrm{~nm}$ using a Spectra Count TM (Packard Instrument Co., Downers Grove, IL, USA) ELISA reader.

\subsection{Cell Cycle Analysis}

The progression of the cell cycle was determined using flow cytometric analysis after staining with PI. Initially, the suspension $\left(2 \times 10^{6}\right.$ cells $)$ of essential oil treated KB cells was fixed with $80 \%$ ethanol at $4{ }^{\circ} \mathrm{C}$ for $12 \mathrm{~h}$, and incubated overnight at $4{ }^{\circ} \mathrm{C}$ with $1 \mathrm{~mL}$ of a PI staining mixture $(250 \mu \mathrm{L}$ of PBS, $250 \mu \mathrm{L}$ of $1 \mathrm{mg} / \mathrm{mL}$ RNase in $1.12 \%$ sodium citrate, and $500 \mu \mathrm{L}$ of $50 \mu \mathrm{g} / \mathrm{mL}$ PI in $1.12 \%$ sodium citrate). After staining, $1 \times 10^{4}$ cells were analyzed using the FACS Caliber ${ }^{\circledR}$ system (Becton Dickinson, San Jose, CA, USA).

\subsection{Nuclear Morphology Analysis}

Morphological changes of apoptotic cells were also examined using fluorescence microscopy. At various concentrations after treating $\mathrm{KB}$ cells with the essential oil, the cells were harvested, fixed with absolute ethanol, and stained with Hoechst 33258 for $15 \mathrm{~min}$ at $37^{\circ} \mathrm{C}$. The cells were then visualized using fluorescence microscopy (Olympus BX50, Tokyo, Japan) with UV excitation at 300-500 nm. Cells containing condensed and/or fragmented nuclei were considered to be apoptotic cells.

\subsection{DNA Extraction and DNA Gel Electrophoresis}

The characteristic ladder pattern of DNA break was analysed by agarose gel electrophoresis. KB cells treated with different concentrations of the essential oil for $12 \mathrm{~h}$ were collected, washed with PBS twice, and DNA from KB cells was isolated by a Wizard Genomic DNA purification kit (Promega Co., Madison, WI, USA). Isolated genomic DNA was subjected to $2.0 \%$ agarose gel electrophoresis at $100 \mathrm{~V}$ for $1 \mathrm{~h}$. DNA was visualized by staining with ethidium bromide under UV light.

\subsection{Preparation of Cytosolic and Mitochondrial Extract}

The subcellular fractions were prepared as described previously [18]. The harvested pellets were suspended in $100 \mu \mathrm{L}$ of buffer A [20 mM Hepes- $\mathrm{KOH}, \mathrm{pH} 7.5,10 \mathrm{mM} \mathrm{KCl}, 1.5 \mathrm{mM} \mathrm{MgCl}, 1 \mathrm{mM}$ sodium EDTA, $1 \mathrm{mM}$ sodium EGTA, $1 \mathrm{mM}$ dithiothreitol (DTT; Sigma), $1 \mu \mathrm{g} / \mathrm{mL}$ aprotinin, $100 \mu \mathrm{g} / \mathrm{mL}$ phenylmethyl-sulfonylfluoride (PMSF; Sigma), and $250 \mathrm{mM}$ sucrose]. After incubate on ice for $10 \mathrm{~min}$, homogenize cells in an ice-cold dounce tissue grinder (45 strokes) until $70-80 \%$ of the nuclei did not have the shiny ring and centrifuge at $700 \times \mathrm{g}$ for $10 \mathrm{~min}$ at $4{ }^{\circ} \mathrm{C}$. The supernatant was 
collected and further centrifuged at $10,000 \times \mathrm{g}$ for $30 \mathrm{~min}$ at $4{ }^{\circ} \mathrm{C}$ to isolate cytosolin fraction. Cytosolic fraction was stored at $-80{ }^{\circ} \mathrm{C}$ until ready for Western blotting.

\subsection{Western Blot Analysis}

Equal amount of protein (40 $\mu \mathrm{g} /$ sample) was separated electrophoretically by $10-12 \%$ SDS-PAGE and blotted onto PVDF membranes. The blots were probed with the primary antibodies and incubated with a horseradish peroxidase-conjugated anti-IgG in blocking buffer for $1 \mathrm{~h}$. After washing, the blots were developed with ECL (Santa Cruz Biotechnology, Santa Cruz, CA, USA) and exposed to X-ray film (Eastman-Kodak, Rochester, NY, USA). The polyclonal antibodies specific to Bcl-2 (SC-783, 1:200), caspase-3 (SC-7148, 1:200), caspase-8 (SC-6134, 1:100), and PARP (SC-7150, 1:200), and the monoclonal antibodies specific to Bax (SC-7480, 1:100), cytochrome $c$ (SC-13156, 1:500), and caspase-9 (SC-17784, 1:100) were purchased from Santa Cruz Biotechnology. The polyclonal antibody specific to $\beta$-actin (1:500) was purchased from Sigma Chemical Co.

\subsection{Statistical Analysis}

All the data are expressed as a mean \pm standard error (SE). One-way ANOVA using SPSS ver. 10.0 software was used for multiple comparisons. A $p<0.05$ was considered significant.

\section{Conclusions}

This study demonstrates that the essential oil of $C$. japonica induces apoptosis through mitochondrial- and caspase-dependent mechanisms. However, identifying the active components responsible for the apoptosis inducing activity is quite difficult because the essential oil of $C$. japonica contains a large number of components [15]. Terpinen-4-ol, $\alpha$-pinene, $\alpha$-terpineol, and sabinene are naturally occurring monoterpenes found in the essential oils of many aromatic plants that have been shown to have anticancer effects as well as antioxidant and anti-inflammatory activities [30-33]. Overall, the essential oil of $C$. japonica may have potential as a cancer chemopreventive and therapeutic agent.

\section{Acknowledgements}

This paper was supported in part by research funds of Ulsan College.

\section{Conflict of interest}

The authors have declared no conflict of interest.

\section{References}

1. Gradzka, I. Mechanisms and regulation of the programmed cell death. Postepy Biochem. 2006, 52, 157-165.

2. White, B.C.; Sullivan, J.M. Apoptosis. Acad. Emerg. Med. 1998, 5, 1019-1029. 
3. Roos, W.P.; Kaina, B. DNA damage-induced cell death by apoptosis. Trends Mol. Med. 2006, 12, 440-450.

4. Wang, C.; Youle, R.J. The role of mitochondria in apoptosis. Annu. Rev. Genet. 2009, 43, 95-118.

5. Orrenius, S. Mitochondrial regulation of apoptotic cell death. Toxicol. Lett. 2004, 149, 19-23.

6. Nalepa, G.; Zukowska-Szczechowska, E. Caspases and apoptosis: Die and let live. Wiad. Lek. 2002, 55, 100-106.

7. Scorrano, L.; Korsmeyer, S.J. Mechanisms of cytochrome $c$ release by proapoptotic Bcl-2 family members. Biochem. Biophys. Res. Commun. 2003, 304, 437-444.

8. Cho, S.G.; Choi, E.J. Apoptotic signaling pathways: Caspases and stress-activated protein kinases. J. Biochem. Mol. Biol. 2002, 35, 24-27.

9. Crowell, P.L. Prevention and therapy of cancer by dietary monoterpenes. J. Nutr. 1999, 129, 775S-778S.

10. Allen, R.T.; Hunter, W.J., 3rd; Agrawal, D.K. Morphological and biochemical characterization and analysis of apoptosis. J. Pharmacol. Toxicol. Methods 1997, 37, 215-228.

11. Tamura, Y.; Sasaki, R.; Inouye, S.; Kawaguchi, J.; Serizawa, N.; Toda, M. Identification of a sequential B-cell epitope on major allergen (Cry j 1) of Japanese cedar (Cryptomeria japonica) pollen in mice. Int. Arch. Allergy Immunol. 2000, 123, 228-235.

12. Yasueda, H.; Yui, Y.; Shimizu, T.; Shida, T. Isolation and partial characterization of the major allergen from Japanese cedar (Cryptomeria japonica) pollen. J. Allergy Clin. Immunol. 1983, 71, $77-86$.

13. Matsunaga, T.; Hasegawa, C.; Kawasuji, T.; Suzuki, H.; Saito, H.; Sagioka, T. Isolation of the antiulcer compound in essential oil from the leaves of Cryptomeria japonica. Biol. Pharm. Bull. 2000, 23, 595-598.

14. Miura, H.; Kawano, N.; Waiss, A.C., Jr. Cryptomerin A and B, hinokiflavone methyl ethers from the leaves of Cryptomeria japonica. Chem. Pharm. Bull. 1966, 14, 1408-1413.

15. Cha, J.D.; Jeong, M.R.; Jeong, S.I.; Moon, S.E.; Kil, B.S.; Yun, S.I.; Lee, K.Y.; Song, Y.H. Chemical composition and antimicrobial activity of the essential oil of Cryptomeria japonica. Phytother. Res. 2007, 21, 295-299.

16. Cheng, S.S.; Chang, S.T. Antitermitic activity of essential oils from Cryptomeria japonica. Quart. J. Chin. For. 2002, 35, 193-199.

17. Cheng, S.S.; Chua, M.T.; Chang, E.H.; Huang, C.G.; Chen, W.J.; Chang, S.T. Variations in insecticidal activity and chemical compositions of leaf essential oils from Cryptomeria japonica at different ages. Bioresour. Technol. 2008, 100, 465-470.

18. Kluck, R.; Bossy-Wetzel, E.; Green, D.R.; Newmeyer, D.D. The release of cytochrome $c$ from mitochondria: A primary site for Bcl-2 regulation of apoptosis. Science 1997, 275, 1132-1136.

19. Budihardjo, I.; Oliver, H.; Lutter, M.; Luo, X.; Wang, X. Biohemical pathways of caspase activation during apoptosis. Annu. Rev. Cell Dev. Biol. 1999, 15, 269-290.

20. Yang, J.; Liu, X.; Bhalla, K.; Kim, C.N.; Ibrado, A.M.; Cai, J.; Peng, T.I.; Jones, D.P.; Wang, X. Prevention of apoptosis by Bcl-2: Release of cytochrome $c$ from mitochondria blocked. Science 1997, 275, 1129-1132. 
21. Ray, R.S.; Ghosh, B.; Rana, A.; Chatterjee, M. Suppression of cell proliferation, induction of apoptosis and cell cycle arrest: chemopreventive activity of vanadium in vivo and in vitro. Int. J. Cancer 2007, 120, 13-23.

22. Lavrik, I.N.; Golks, A.; Krammer, P.H. Caspases: Pharmacological manipulation of cell death. J. Clin. Invest. 2005, 115, 2665-2672.

23. Cha, J.D.; Jeong, M.R.; Kim, H.Y.; Lee, J.C.; Lee, K.Y. MAPK activation is necessary to the apoptotic death of $\mathrm{KB}$ cells induced by the essential oil isolated from Artemisia iwayomogi. J. Ethnopharmacol. 2009, 123, 308-314.

24. Sylvestre, M.; Pichette, A.; Longtin, A.; Nagau, F.; Legault, J. Essential oil analysis and anticancer activity of leaf essential oil of Croton flavens L. from Guadeloupe. J. Ethnopharmacol. 2006, 103, 99-102.

25. Li, X.; Darzynkiewicz, Z. Cleavage of Poly (ADP-ribose) polymerase measured in situ in individual cells: Relationship to DNA fragmentation and cell cycle position during apoptosis. Exp. Cell Res. 2000, 255, 125-132.

26. Norbury, C.J.; Zhivotovsky, B. DNA damage-induced apoptosis. Oncogene 2004, 23, 2797-2808.

27. Soldani, C.; Scovassi, A.I. Poly (ADP-ribose) polymerase-1 cleavage during apoptosis: An update. Apoptosis 2002, 7, 321-328.

28. Er, E.; Oliver, L.; Cartron, P.F.; Juin, P.; Manon, S.; Vallette, F.M. Mitochondria as the target of the pro-apoptotic protein Bax. Biochim. Biophys. Acta 2006, 1757, 1301-1311.

29. Kirkin, V.; Joos, S.; Zornig, M. The role of Bcl-2 family members in tumorigenesis. Biochim. Biophys. Acta 2004, 1644, 229-249.

30. Barra, A.; Coroneo, V.; Dessi, S.; Cabras, P.; Angioni, A. Characterization of the volatile constituents in the essential oil of Pistacia lentiscus 1 . from different origins and its antifungal and antioxidant activity. J. Agric. Food Chem.2007, 55, 7093-7098.

31. Zúñiga, B.; Guevara-Fefer, P.; Herrera, J.; Contreras, J.L.; Velasco, L.; Pérez, F.J.; Esquivel, B. Chemical composition and anti-inflammatory activity of the volatile fractions from the bark of eight Mexican Bursera species. Planta Med. 2005, 71, 825-828.

32. Calcabrini, A.; Stringaro, A.; Toccacieli, L.; Meschini, S.; Marra, M.; Colone, M.; Salvatore, G.; Mondello, F.; Arancia, G.; Molinari, A. Terpinen-4-ol, the main component of Melaleuca alternifolia (Tea Tree) oil inhibits the in vitro growth of human melanoma cells. J. Invest. Dermatol. 2004, 122, 349-360.

33. Deeb, S.J.; E1-Baba, C.O.; Hassan, S.B.; Larsson, R.L.; Gali-Muhtasib, H.U. Sage components enhance cell death through nuclear factor kappa-B signaling. Front. Biosci. (Elite Ed.) 2011, 3, $410-420$.

Sample Availability: Not available.

(C) 2012 by the authors; licensee MDPI, Basel, Switzerland. This article is an open access article distributed under the terms and conditions of the Creative Commons Attribution license (http://creativecommons.org/licenses/by/3.0/). 